\title{
Supply and usage of hemodynamic services in the state of Rio de Janeiro, Brazil
}

\author{
Oferta e utilização de serviços de hemodinâmica no estado do Rio de Janeiro, \\ Brasil
}

Maria de Fatima Sillansky de AndreazzI'; Marco Antonio Ratzsch de AndreazzI'; Leyla Sancho3; Heitor Alarico Gonçalves de

FrEITAS $^{3}$

\author{
A $B$ S S T R A C T
}

\begin{abstract}
Objective: To analyze the supply of equipment and procedures inherent to public hemodynamic services in the State of Rio de Janeiro, Brazil. Methods: We conducted an exploratory study based on official data banks: AMS survey of IBGE, CNES, AlH and APAC, and ANS. The examination period of the supply was from 1999 to 2009, and of the use, from 2008 to October 2012. Results: Since 1999 there has been a growth in the acquisition of hemodynamic equipment. The private sector concentrates most of the offer, but has been reducing its availability to the Unified Health System (SUS). The ratio of the equipment and the population exceeds that of some rich countries. On the supply side, there was, in Rio de Janeiro, in 2009, a rate of 4.1 units per million inhabitants, higher than in Brazil as a whole, of 3.4; however, when considering only the offer for the SUS (SUS), the values are similar, 1.6 and 1.5. Conclusion: The procedures of interventional cardiology grew between 2008 and 2011 in Rio de Janeirio, but the majority of public hospitals have reduced production and the private have increased it, resulting in the referral of SUS users to be submitted to procedures great distances from home.
\end{abstract}

Key words: Angioplasty.Cardiac. Catheterization. Hemodynamics. Health services/Utilization. Health economics.

\section{INTRODUCTION}

Sistents ince the 1960s, interventional procedures using X-rays have increased significantly and continue to grow as less invasive technology and equipment with increasingly sophisticated techniques are being developed. Thus, complicated operations are replaced by simple medical procedures, reducing the risk and the length of stay for the patient, and lower total cost ${ }^{1}$.

The judicious use of diagnostic imaging methods has increased the effectiveness of health care; however, the upward trend of costs has been attributed to the incorporation of technology in health care, including diagnostic techniques and therapeutic imaging 2,3 . Moreover, the excess supply leads to overuse of services ${ }^{4}$. This behavior carries risks for patients and for professionals who perform the procedures ${ }^{1,5}$.

In Brazil, there are no systematic methods governing the acquisition of equipment in public and private health services ${ }^{4}$. In a context of growing concern about this issue in the 2000s, a national policy for the management of health technologies was discussed and elaborated, culminating in the enactment, by the Ministry of Health, of the Ordinance No. 2690/2009. It has the general objective to maximize the health benefits to be obtained from the available resources, ensuring people's access to safe and effective technologies in conditions of equity ${ }^{5}$.

Despite the recent efforts of the Ministry of Health, its regulatory role with regard to biomedical technologies is more focused on the authorization of use, through the registration of new technologies from the National Health Surveillance Agency (ANVISA), and on its incorporation by policy coverage and reimbursement from the National Supplemental Health Agency (ANS) and the Health Support Division of the Unified Health System (SUS). The State's role in planning the provision of technologies in general and in particular biomedical equipment is quite limited, and a more relevant may be assigned to medical and health services managers in decisions about the purchase and use ${ }^{6}$

One of the instruments that the SUS uses to regulate the public use is the management of use of the available resources through the regulation system on the providers of direct service and of access to care ${ }^{7}$. In the State of Rio de Janeiro, the State Regulation Center was implemented in 2005 by the State Department of Health (SES), to regulate beds for highly complex procedures, such as those performed in a hemodynamic services. In November

1. Department of Preventive Medicine, Faculty of Medicine, Federal University of Rio de Janeiro, RJ, Brazil; 2. Brazilian Institute of Geography and Statistics - IBGE, RJ, Brazil; 3. Institute for the Study of Collective Health, Federal University of Rio de Janeiro, RJ, Brazil. 
2010, SES partnered with the Municipal Health Department, aimed at the co-management of nine regional control centers located in the State health regions.

Although studies on the diffusion of biomedical equipment, especially radiology, are more frequent in the literature ${ }^{8-10}$, they already appear in the Brazilian context 6,11-13. Silva and Viana ${ }^{6}$ and Viana and Silva ${ }^{12}$, addressing the computed tomography scanner, concluded that the diffusion of this equipment in Brazil had little to do with health needs and reimbursement decisions by public or private funders. The most important explanatory element were decisions of managers of private health organizations strongly influenced by doctors and the industry producing this equipment, seeking a strategy to meet competition for product differentiation. Understanding that diffusion is the stage of adoption and use of technology that must culminate in the achievement of an appropriate level of use or in its abandonment ${ }^{8,14}$.

The hemodynamic procedures can be considered a mature technology ${ }^{15}$, used since the 40 's. Innovations were being added to the techniques that increase their efficiency: the use of contrast (60), the digitization of images (70), the therapeutic procedures, such as balloon Percutaneous Transluminal Coronary Angioplasty (PTCA 1977) ${ }^{1}$.

In Brazil, the first examinations in hemodynamics began in 1966, the first PTCA being held in $1979{ }^{16}$. In the last 30 years PTCA spread quickly as an alternative to Coronary Artery Bypass Grafting (CABG). In the 90s, the association of PTCA with the use stents - vascular endoprostheses - increased the diffusion of this procedure by lowering the rate of restenosis ${ }^{17}$. In the late 2000s, Drug-eluting stents were incorporated, seeking an even lower rate of restenosis.

Still in the 2000s, the great innovation in equipment occurred for diagnostic studies, CT angiography, with the incorporation of multi-detector computed tomography $(\mathrm{MDCT})^{18}$, which dispenses catheters and allow contrast to be introduced intravenously, reducing the time and radiation load involved in the examination.

Gutierrez $^{17}$ concluded that PTCA, compared to other technologies, has had a very rapid diffusion, which is consistent with the expansion of the supply of X-Ray hemodynamics equipment. The guidelines of the Brazilian Society of Interventional Cardiology - $\mathrm{SBHCl}{ }^{19}$ specify that these services must contain, in addition to equipment, skilled human resources.

In Brazil, the benchmark for healthcare coverage of imaging equipment for the SUS (Ordinance No. 1101 / GM of June $12^{\text {th }}, 2002$ ) does not specify the need for hemodynamic X-Ray devices.

Studies of supply and use of health services using official databases have particular utility in the process of technology diffusion, allowing to raise hypotheses regarding the determinants and impacts and to contribute to management decision making.
Offer is understood here as a set of resources that are available. In an economic sense, the offer has to do with the quantities that are offered by firms from a price curve. In the case of free public offer, one can not speak of firms, but of organizations in a context of zeroed prices. Therefore, the motivations of private or public economic agents are distinct, the former aiming profits and survival in the market, the latter aiming at other motivations. The supply is determined by technology, managerial experience of firms and organizations, and the price of inputs used ${ }^{20}$.

Use implies a relationship between demand and supply and results from the interaction of the behavior of the individual seeking care and the professional managing the individual within the health system. The determinants of use are related to health needs, the characteristics of users, service providers, policy, and funding and regulation; the determinants of the organization, on their turn relate to where available resources are allocated and characteristics of the supply, the availability of doctors, hospitals, clinics, payment policy and the social and geographical access to care $^{21}$.

Given these facts, having as object the services of hemodynamics, the study consisted of an analysis of the pattern of supply of equipment and the use of procedures in the public services in the State of Rio de Janeiro.

\section{METHODS}

This exploratory study was quantitative, taking as the official source of the data the official databases of SUS, of the National Agency of Health and of the Brazilian Institute of Geography and Statistics, namely: the National Registry of Health Facilities - CNES, with limit on 2012, according to tables obtained through the online softwares Tabnet and DATASUS Tabwin; SUS Outpatient Information System / CIS and Hospital / SIH SUS; APAC (referring to the SUS attention of high complexity); Information System of Beneficiaries of ANS; Medical and Health Care Research / AMS, in versions 1999, 2002, 2005 and 2009; and the Population Census, whose data are in the IBGE Multidimensional Statistics Database. There are some differences in results between the CNES and the AMS, but we opted for the AMS to evaluate the time evolution of supply, due to the greater stability of historical data, and CNES to evaluate the offer of 2012 and its relationship with the production of SUS services. All these data are freely obtained on the websites of the respective institutions. Data will be presented in simple frequencies and geographic flows.

The use of Hemodynamics was only obtained for the procedures financed by SUS. Electronic files of ambulatory and hospital production were obtained from 2008 to October 2012, downloaded through MS / BBS using the codes of procedures that include cardiac catheterization (codes 0211020010 and 0211020028), angioplasty, valve 
repair and electrophysiological studies / ablation (codes 04060300 to 0406050139 ). The option for 2008 was due to the implementation of a new table of outpatient hospital procedures on that year, without direct correspondence with previous years.

The total population was the one estimated from the census, obtained from DATASUS, and the population with health care plans was gathered from the information of recipients of ANS / SIB in the middle of the period.

The variables used for the analysis of supply were: number of hemodynamic equipment in use by one million inhabitants, distributed according to legal nature, availability to SUS and selected regions, and calculating the rates of change within the period of analysis, which was from 1999 until 2012. The estimation of the rate of supply of equipment to beneficiaries of private health plans was possible from the use of the registry of beneficiaries of the ANS, the denominator being the number of private equipment listed as unavailable to SUS, both in CNES at and in the AMS research.

For usage analysis, the variables were: number and crude rate per 100,000 population, total expenditure and average value of selected hemodynamic SUS procedures, according to selected regions of the State of Rio de Janeiro. Furthermore, we used rates of change, the period considered for utilization studies being between 2008 and 2012. Despite the current existence of a large database of utilization of health services by the target population of private plans health within the ANS, the hemodynamic procedures studied are not shown individually, which does not allow comparative studies.

Contrary to the case of other equipment for diagnostic imaging (through Ordinance 1101 / GM / 2002), there are no benchmarks for certain indicators such as rate of supply of hemodynamic equipment and utilization of selected procedures. Our choice was to compare the values found with international findings and patterns taken from health services regulators from other countries.

The study complied with Resolution 196/96 of the National Health Council, and was approved by the Ethics in Research Committee of the Clementino Fraga Filho University Hospital and Faculty of Medicine of UFRJ, opinion dated October $18^{\text {th }}, 2012$, CEP protocol number $019 / 11$.

\section{RESULTS}

In 2009, according to the AMS / IBGE research, Brazil had $654 \times$ Ray equipment for hemodynamics, 95 public (15\% of the total) and 559 private $(85 \%)$. Of the total, 314 (48\%) were available to SUS. For private facilities, the percentage of the SUS availability was $42 \%$.

In the State of Rio de Janeiro, still according to the same source and year, there were $66 \mathrm{X}$-Ray hemodynamic equipments were identified, 16 public (24\%) and 50 private (78\%). The availability to SUS was $36 \%$, and among the private ones only 12 were available to SUS (24\%).

Between 1999 and 2009, there was a significant growth in the supply of imaging equipment in Brazil, of $51.3 \%$. Public facilities stood out, with $89.2 \%$ growth. The number of X-Ray hemodynamic equipments grew slightly more than the average for the group Image (84.2\%), but more significant changes occurred for the equipments for computed tomography, with $99.3 \%$ and magnetic resonance imaging, with $320.7 \%$. (Table 1).

In Rio de Janeiro, the rate of change of X-Ray to hemodynamics between 1999 and 2009 was much lower than that found in Brazil, 17.9\%, with 14.3\% for the public sector and $19.0 \%$ for the private. This occurred with the sector image as a whole in the State, which showed an increase of $16.3 \%$. Between 2005 and 2009 the number of X-Ray hemodynamics equipments in Rio de Janeiro located in public establishments, remained virtually unchanged.

Regarding the population coverage, in 2009 there was 3.4 X-Ray hemodynamic equipments per million population in Brazil, rhis rate being higher in the State of Rio de Janeiro (4.1). Considering only the equipment available to SUS, this coverage becomes 1.6 per million in Brazil and 1.5 in Rio de Janeiro.

When using a more updated source, CNES, in November 2012 there were 92 X-Ray hemodynamics equipments in the State of Rio de Janeiro, 16 public, 15 philanthropic and 61 private; among the public, nine offered service to SUS clients, all located in the capital. The coverage of the equipment at the Metropolitan Health Region I, which includes the capital, was 5.6 equipments per million people, not much different from that of the State average, which was 5.7. However, the estimated coverage for the SUS was higher in the State, of 1.7 per million people, compared with 1.5 in the Metropolitan Health Region I. Noteworthy is the Northwest Health Region, with a total of 18 equipments per 1 million inhabitants and the availability to SUS of 6.0 , with 6 private providers, two of them offering services to SUS (Table 2).

In the State of Rio de Janeiro, from 2008 to 2012 there has been a steady increase in the number of cardiology procedures performed in hemodynamics services funded by the SUS, as well as increase in relation to the population. For the total of procedures, the average annual rate of increase was $16.4 \%, 11 \%$ for outpatients and $32.6 \%$ for in-hospital procedures. The annual rate of increase in coronary angioplasty was $36.2 \%$. The relationship between ambulatory and hospital procedures was $68.7 \%$ in the period. Of the therapeutic procedures, coronary angioplasty represented the most frequent group, $78 \%$ in the entire period. Of these, $91 \%$ involved the implantation of stents, $59 \%$ being one stent, and $31 \%$, two. We also observed an increase in the gross rate of procedures, which reached 106.2 per 100,000 inhabitants in 2011, reaching 159.4 per 100,000 inhabitants if we do not consider the beneficiary 
Table 1 - Number of Image equipment selected and percentage change in the period, by legal nature, Brazil and Rio de Janeiro, in 1999 and 2009.

\begin{tabular}{|c|c|c|c|c|c|c|c|c|c|c|}
\hline \multirow{3}{*}{$\begin{array}{l}\text { Type of } \\
\text { Equipament }\end{array}$} & \multirow{3}{*}{$\begin{array}{l}\text { Geographic } \\
\text { Region }\end{array}$} & \multicolumn{3}{|c|}{ Total } & \multicolumn{3}{|c|}{ Private } & \multicolumn{3}{|c|}{ Public } \\
\hline & & 1999 & 2009 & variation & 1999 & 2009 & variation & 1999 & 2009 & variation \\
\hline & & & \multicolumn{3}{|c|}{$1999-2009$} & \multicolumn{3}{|c|}{$1999-2009$} & \multicolumn{2}{|r|}{ 1999-2009 } \\
\hline Total Imaging & Brazil & 32.789 & 49.598 & $51.3 \%$ & 27.072 & 38.781 & $43.3 \%$ & 5.717 & 10.817 & $89.2 \%$ \\
\hline Diagnostic & Rio de Janeiro & 5.142 & 5.982 & $16.3 \%$ & 4.205 & 5.706 & $35.7 \%$ & 937 & 1.700 & $81.4 \%$ \\
\hline \multicolumn{11}{|l|}{ Equipment $(*)$} \\
\hline \multirow{2}{*}{$\begin{array}{l}\text { X-Ray equipment } \\
\text { for hemodynamics }\end{array}$} & Brazil & 355 & 654 & $84.2 \%$ & 285 & 559 & $96.1 \%$ & 70 & 95 & $36 \%$ \\
\hline & Rio de Janeiro & 56 & 66 & $17.9 \%$ & 42 & 50 & $19.0 \%$ & 14 & 16 & $14.3 \%$ \\
\hline Computerized & Brazil & 1.515 & 3.019 & $99.3 \%$ & 1.375 & 2.637 & $91.8 \%$ & 140 & 382 & $173 \%$ \\
\hline Tomography & Rio de Janeiro & 178 & 363 & $103.9 \%$ & 148 & 287 & $93.9 \%$ & 35 & 76 & $117.1 \%$ \\
\hline Magnetic Resonance & Brazil & 285 & 1.199 & $320.7 \%$ & 266 & 1.130 & $324.8 \%$ & 19 & 69 & $263 \%$ \\
\hline Imaging & Rio de Janeiro & 49 & 200 & $308.2 \%$ & 45 & 189 & $320.0 \%$ & 4 & 11 & $175.0 \%$ \\
\hline
\end{tabular}

(*) Except imaging equipment in Dentistry.

Source: IBGE, Medical and Health Care Research, 1999 and 2009

population of private health plans in the denominator (Table 3).

When analyzing the supply and use of services performed for inpatient procedures in Interventional Cardiology in health regions of Rio de Janeiro, according to data from the SIH-SUS / DATASUS, only the Bay of llha Grande Region has no service to perform these procedures, requiring that $88 \%$ of these procedures be performed in the Middle Paraíba Region. The other regions meet most of their demands, especially the Northwest, which requires that only $1.8 \%$ of such procedures be conducted outside the Region, and the Metropolitan II, where about $40 \%$ are referred to other regions, mainly for the Coastal Lowlands. The Coastal Lowlands is the region that most supplies to other regions, representing over $40 \%$ of its total admissions recorded in the period of analysis; of these, about $80 \%$ are from the Metropolitan Region (I and II).

Figure 1 depicts the flow of admissions among municipalities of the Rio de Janeiro Health Regions. The lines originate in the municipalities of residence of the patient and end in the city of hospitalization. The fractions of circles show the proportion of procedures performed for the population of the city or referred from others. It is noteworthy the proportion of admissions for other municipalities in Vassouras, where $92 \%$ of admissions for interventional cardiology procedures were from other towns, especially Três Rios, responsible for $23 \%$ of them. Cabo Frio also features high proportion of admissions from other municipalities (80\%), while Rio de Janeiro held only $30 \%$ of their admissions to care for other municipalities.

Table 2 - Number of X-ray equipment for Hemodynamics in use by Health Region and Administrative Sphere, availability to SUS and offer rate, Rio de Janeiro, 2012.

\begin{tabular}{|c|c|c|c|c|c|c|}
\hline \multirow[t]{2}{*}{ Health Region } & \multirow[b]{2}{*}{ Total } & \multicolumn{2}{|l|}{ Public } & Private & \multirow{2}{*}{$\begin{array}{l}\text { Total supply } \\
\text { (per million } \\
\text { inhabitants) }\end{array}$} & \multirow{2}{*}{$\begin{array}{c}\text { Supply available } \\
\text { to suS } \\
\text { (per million } \\
\text { inhabitants) }\end{array}$} \\
\hline & & $\begin{array}{c}\text { Available } \\
\text { to SUS }\end{array}$ & Total & $\begin{array}{c}\text { Available } \\
\text { to SUS }\end{array}$ & & \\
\hline Ilha Grande Bay & 0 & 0 & 0 & 0 & 0 & 0 \\
\hline Coastal Lowlands & 0 & 0 & 4 & 1 & 5.6 & 1.4 \\
\hline South-Central & 0 & 0 & 1 & 1 & 3.1 & 3.1 \\
\hline Medium Paraíba & 0 & 0 & 3 & 2 & 3.5 & 2.3 \\
\hline Metropolitan I & 15 & 8 & 41 & 7 & 5.6 & 1.5 \\
\hline Metropolitan II & 1 & 1 & 12 & 2 & 6.6 & 1.5 \\
\hline Northwest & 0 & 0 & 6 & 2 & 18.0 & 6.0 \\
\hline North & 0 & 0 & 7 & 2 & 8.1 & 2.3 \\
\hline Mountains & 0 & 0 & 2 & 1 & 2.2 & 1.1 \\
\hline Total & 16 & 9 & 76 & 18 & 5.7 & 1.7 \\
\hline
\end{tabular}

Source: Ministry of Health - National Register of Health Establishments of Brazil - CNES. 
Table 3 - Number of selected procedures of Interventional Cardiology (IC) and rate per 100,000 inhabitants, Rio de Janeiro, 2008-2011.

Procedures 200820092010

Number of Permits of $\mathrm{Cl}$ Outpatient Procedures (APAC)

Number of Authorizations for $\mathrm{Cl}$ Hospitalizations (AlH)

Total number of $\mathrm{Cl}$ procedures

APAC-Cl / Total Cl procedures Ratio (\%)

$\mathrm{Cl}$ procedures per 100.000 population

$\mathrm{Cl}$ procedures per 100.000 inhabitants (no health insurance *) Coronary angioplasty procedures per 100.000 population Coronary angioplasty procedures per 100.000 inhabitants (no health insurance *)
8583

2874

2164

1145

\section{6 \\ 9650}

4355

3220

1246

1

65.1

77.8

124.0

72.2

118.0

2

13.6

6

20.1

53.5
4828

3750

1447

8

66.7

90.5

138.0

7

23.5

67.5

Source: Ministry of Health - DATASUS - SUS Outpatient and Hospital Information System, 2012.(*) The population beneficiary of private health insurance was withdrawn from the denominator - ANS, 2012.

Table 4 brings a list of 22 hospitals in the State that, between 2008 and 2012, had hospital admission authorizations $(\mathrm{AlH})$ related to invasive percutaneous procedures in cardiology. By adding up the production in the period we observed that a public hospital specialized in Cardiology stood out with the highest number of admissions, but also three public hospitals were those with smaller amounts.

By verifying the evolution of procedures by type of provider, one confirms the simultaneous stagnation of production of public hospitals and private output growth, which occurred mainly after 2010.

As for expenditures, in $2008 R \$ 16,618,985.71$ were spent with Cardiology percutaneous invasive procedures in Rio de Janeiro, expenses which rose up to $\mathrm{R} \$ 33,337,751.44$ in 2011. This growth was more due to the increase of the volume of procedures than to the average value, as this varied little, from $R \$ 5,782.53$ in 2008 to $\mathrm{R} \$ 5,865.19$ in 2011, close to the Brazilian average, $\mathrm{R} \$ 5,872.29$, but smaller than the Southeast average, $\mathrm{R} \$ 6,063.35$. There was a tendency to increase in the participation of these procedures in $\mathrm{AlH}$ expenditures in Rio de Janeiro, from 4\% in 2008 to $5 \%$ in 2012. We also found a decrease in the overall expenditure of public providers, as opposed to an increase of private ones, after 2010. The average value of the procedures in the period was higher for philanthropic providers ( $R \$ 6,687.23$ ), followed by the private ( $R \$ 5,818.34)$, and finally public ones ( $R \$ 4,903.77)$. The average values for the period were higher in the interior regions than in the capital microregion, ranging from $R \$ 7,836.47$ in Itaperuna to $R \$ 5,110.61$ in Rio de Janeiro.

This information about costs of hospitalization in public hospitals should be analyzed with caution, because the values passed by providing services to the SUS procedures table do not comprise the total expenses of these hospitals.

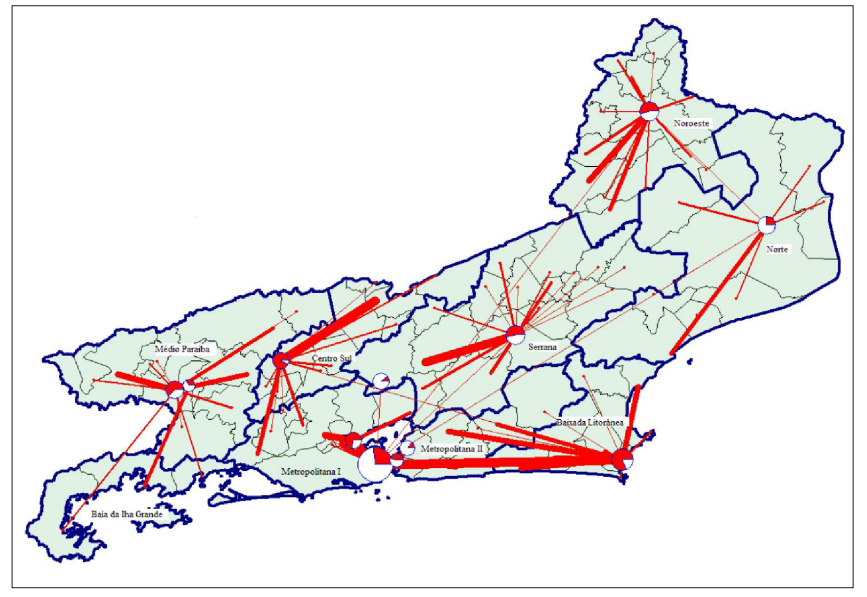

Figure 1 - Representation of hospitalizations flows $(\mathrm{AlH})$ for selected Interventional Cardiology procedures among municipalities and Health Regions. Rio de Janeiro, from 2008 to 2012 (October).

\section{DISCUSSION}

Since the late 90 s, there has been a maintained growth of the supply of imaging equipment in Brazil, in both the public and the private sectors. The amount of $X$ ray equipment for hemodynamics purposes also increased, although to a lesser extent in relation to other complex equipment, such as CT scanners and MRI apparatuses, which are more recently introduced technologies. The X-Ray equipment for hemodynamics also prevailed in the private sector, with an availability to SUS smaller than the image sector as a whole, and declining between 1999 and 2009, from $66 \%$ to $48 \%$.

The variation in Rio de Janeiro in this period, on its turn, was lower than the Brazilian one for the image industry and the hemodynamics in particular, suggesting a prior distribution with relative stabilization, since the rate of supply of such equipment is largest in the State, which is 
Table 4 - Number of Hospitalizations of Interventional Cardiology, by Hospital, according to county and type of provider, Rio de Janeiro, 2008-2012.

\begin{tabular}{|c|c|c|c|c|c|c|c|}
\hline $\begin{array}{l}\text { Municipality/ } \\
\text { hospital }\end{array}$ & $\begin{array}{l}\text { Type of } \\
\text { provider }\end{array}$ & 2008 & 2009 & 2010 & 2011 & 2012 & Total \\
\hline Campos 1 & Philanthropic & 101 & 141 & 161 & 268 & 184 & 855 \\
\hline Campos 2 & Philanthropic & 116 & 145 & 91 & 102 & 75 & 529 \\
\hline Itaperuna & Philanthropic & 505 & 694 & 479 & 533 & 420 & 2631 \\
\hline Cabo Frio & Private & 459 & 661 & 577 & 556 & 483 & 2736 \\
\hline Nova Friburgo & Private & 235 & 285 & 347 & 376 & 268 & 1511 \\
\hline Rio de Janeiro 1 & Public & 104 & 788 & 745 & 965 & 642 & 3244 \\
\hline Duque de Caxias & Private & 0 & 0 & 128 & 486 & 443 & 1057 \\
\hline Rio de Janeiro 2 & Public & 82 & 160 & 313 & 231 & 231 & 1017 \\
\hline São Gonçalo & Private & 321 & 160 & 144 & 208 & 180 & 1013 \\
\hline Rio de Janeiro 3 & Public & 288 & 168 & 259 & 151 & 76 & 942 \\
\hline Rio de Janeiro 4 & Public & 70 & 82 & 62 & 138 & 260 & 612 \\
\hline Niterói 1 & Public & 1 & 64 & 105 & 92 & 94 & 356 \\
\hline Niterói 2 & Private & 0 & 0 & 106 & 124 & 129 & 359 \\
\hline Rio de Janeiro 5 & Public & 49 & 70 & 58 & 27 & 16 & 220 \\
\hline Rio de Janeiro 6 & Public & 54 & 39 & 22 & 3 & 0 & 118 \\
\hline Rio de Janeiro 7 & Public & 3 & 16 & 5 & 0 & 0 & 24 \\
\hline Rio de Janeiro 8 & Public & 0 & 0 & 0 & 0 & 1 & 1 \\
\hline Petrópolis & Philanthropic & 106 & 175 & 221 & 275 & 256 & 1033 \\
\hline Barra Mansa & Philanthropic & 154 & 467 & 545 & 717 & 634 & 2517 \\
\hline Volta Redonda 1 & Private & 116 & 75 & 127 & 138 & 117 & 573 \\
\hline Volta Redonda 2 & Public & 0 & 1 & 1 & 0 & 0 & 2 \\
\hline Vassouras & Philanthropic & 110 & 164 & 332 & 294 & 258 & 1158 \\
\hline Total & 2874 & 4355 & 4828 & 5684 & 4767 & 22508 & \\
\hline
\end{tabular}

Source: Ministry of Health - DATASUS - SUS Outpatient and Hospital Information System, 2012.

compatible with the level of technological development in major referral centers in the Southeast. The availability of the hemodynamics X-Ray equipment to SUS in the State is also declining, and is lower than in Brazil, 36\% in 2009.

The particularity of X-Ray for hemodynamics, both in Brazil and in Rio de Janeiro, is its little significant expansion in public facilities, even in comparison with other high-cost equipment. Although considered a mature technology, its expansion pattern reveals a shift to private clients. To understand the small expansion in public establishments, further analysis of the economic dynamics of the publicprivate mix, especially regarding human resources, is required.

In Brazil, there is usage of indicators of adequate coverage of some imaging equipment. Oh et al. ${ }^{10}$ consider that it may not be practical to have a good standard of supply, but it is useful to compare the diffusion in different countries. In our study, in 2009 the rate of supply of X-Ray equipment for hemodynamics per million inhabitants of 3.4 for Brazil and 4.1 for Rio de Janeiro. However, the estimated coverage for patients undergoing examinations through SUS is much smaller, being 1.6 for Brazil, and for Rio de Janeiro, 1.5 .

A sharp inequality in supply and therefore in the possibilities of population access to this service can be viewed when we estimate the relationship between equipment not available to SUS and the population beneficiary of health plans: 8.2 per million in Brazil and 7.2 in Rio de Janeiro, rates that are even more distant from those offered by SUS. Ko et al. ${ }^{22}$ found a variation in the supply of hospitals with PTCA of 2.5 to 3.5 per million adults in the State of New York between 1997 and 2006, and in Ontario, from 1.0 to 1.4. The comparison with our study requires adjustments in the count of the establishments with hemodynamic services and not of the equipment, and in the population, excluding those with less than 20 years of age from the denominator. After these adjustments, the rates found in hospitals with X-Ray equipment for hemodynamics per million for the population 20 years or older were 4.2 in the total supply in Brazil and 5.0 in Rio de Janeiro, higher values than the rate of NY State, where private participation in the health system is downright dominant. For the provision of SUS, the adjusted values were 2.0 for Brazil and 1.5 for Rio de Janeiro, closer to the province of Ontario, a system of publicly financed health. In Italy ${ }^{23}$, the gross rate of hemodynamics equipment per million population was between 0.8 to 1.7 between 1983 and 1993, with geographical variations that favored the more industrialized North (0.9 to 2.2). Nevertheless, the study period was prior to our period of analysis. One must 
consider, however, the differences in population structure between Brazil and these other countries, which probably increases the need for the service in those countries. In the State of Rio de Janeiro, although almost all health regions present supply of such equipment, it is uneven. The Metropolitan Regions, as would be expected, have the highest rates, but a region of the interior also stands out, even receiving a patient inflow from outside the State. In general, the availability to the SUS by private hospitals is higher in the interior than in the metropolitan area, which relates to the highest proportion of people with private funding sources in richer, industrialized regions, according to SIB / ANS database. Reference rates may be built, but require refined data on health needs and productivity of equipment. Anyway, for private patients and the total supply, the numbers surpass those found in some rich countries.

The increase in supply of X-Ray equipment for hemodynamics in Rio de Janeiro occurs in parallel with the increase of the procedures performed in this service, with the seemingly intensification of its use, because the variation in the number of procedures was higher than that of equipment ${ }^{24}$. Between 2008 and October 2012, the average annual growth rates for the SUS ranged from $11 \%$ (APAC) to $16.4 \%$ (AlH), 36.2\% being for coronary revascularization. In the study by Ko et al. ${ }^{22}$, the annual growth in the number of procedures was much lower, $4.1 \%$ in New York and $5.0 \%$ in Ontario, for cardiac catheterization, and $5.7 \%$ and $10.5 \%$ for PTCA, respectively, from 1997 to 2006 . However, one must take into account the period that was prior to more intensive use of stents. Cardoso et al. ${ }^{25}$ found an average growth of $9 \%$ per year on a historical series from 1998 to 2005, with approximately 1.7 million procedures. In 2012, the OECD (Organization for Economic Cooperation and Development) published a summary of rates of coronary angioplasty found for its member countries ${ }^{26}$. The average annual growth rate presented in that paper, between 2000 and 2010, ranged from 2.3\% (Iceland) to 29.2\% (Romania), lower than in Brazil.

Regarding the use of stents, which were involved in $91 \%$ of coronary revascularization procedures in Rio de Janeiro between 2008 and 2012, similar findings have been already obtained by Mangione 27, 93\% during 2003-2004, from national data on 53,857 percutaneous coronary interventions.

The coverage rate of $C A B G$ procedures ranged from 13.6 per 100,000 in 2008 to 28.0 in 2011. In Romania and in the UK, where data refer only to procedures performed in the public sector, indeed equal to our situation, the rates in 2010 were 53 and 94 per 100,000 residents, respectively ${ }^{26}$. We estimate a closer rate to SUS users, removing the beneficiaries of private health plans from the denominator, finding higher values of 35.0 per 100,000 in 2008 to 83.9 per 100,000 in 2011, and closer to the OECD's findings, but considering the differences in the population. Viacava et al. ${ }^{28}$ also evaluated the rates of coronary angioplasty presented in Brazil as smaller than those observed in most OECD countries. A further deepening of the study, to show potential barriers to patients' access to the method, would involve waiting lists for these procedures in the Central Regulation of SUS.

Rio de Janeiro has a proportion of public X-Ray hemodynamics facilities, relatively higher than Brazil's (24.2\% and $14.5 \%$ in 2009 , respectively). However, there appears to have been an underuse of these public hospitals, especially from 2010, when there was a deviation of the demand for private hospitals, even at considerable distances. Also, these hospitals seem to work with a complexity lower than the one existing in the Southeast region if we consider it as an expression of the average values of the procedures in the period from 2008 to 2012 ( $R \$ 4,903.77$ and $\mathrm{R} \$ 5,878.03$ respectively).

In some examples, there are regulation criteria for the entry of providers, such as the states of Tennessee 29 and West Virginia ${ }^{30}$ located in the USA, by means of instruments called "certificate of need". They are based on geographic distance, where at least $75 \%$ of the target population of a service must reside within 60 miles $(96 \mathrm{~km})$ away. The criteria are off past use (within the last three years available), which has the drawback of incorporating previous distortions. Furthermore, an average productivity of a standard multi-purpose service with 2,000 cases per year is calculated. As a quality criterion, already established since the late $70 \mathrm{~s} 25$, there is a minimum standardized production of 300 cases per year to be achieved within three years.

These criteria can be applied in our case with a greater approximation of the reality in public hospitals, since the private equipment available to SUS often feature a double door entry and the private production is not available for consultation. Across the State of Rio de Janeiro, only one public hospital reached the standard of 2,000 cases in the year 2011. The other hospitals are far from this figure, all located in the microregion and city of Rio de Janeiro that has sent a significant proportion of its patients to Cabo Frio, $150 \mathrm{~km}$ away. As a quality criterion, regarding the achievement of at least 300 tests at the end of three years, six hospitals, all public, could not even reach this figure. Even considering possibilities of glosses and continued absence of information, it can be concluded that problems in public the Rio de Janeiro microregion have meant to SUS users drawbacks related to the long distances covered for treatment in Interventional Cardiology. This flow was also found by Pinto and Pinheiro ${ }^{24}$ and reinforces the need to identify the motivations and constraints that influence the low use of public facilities, while establishing a continuing patient reference flow to certain private hospitals.

Considering the total supply of X-Ray equipment for hemodynamics in Brazil and in the State of Rio de Janeiro, and the inequalities between public and private patients, it can be concluded that the reduction of these inequalities can be reasonably achieved, because more than 
a policy of increase in total supply, it is necessary to improve the capacity of existing resources.

The official databases have been extremely useful to evaluate technology diffusion in Brazil. However, the lack of publicly available information for the private area, such as the beneficiaries of private health plans, prevented the estimated coverage rates of interventional cardiology procedures for this population, which would allow comparisons of coverages from other countries with SUS.

On the other hand, the loss of public ability to assess the amounts actually spent on these procedures is worrisome, due to the loss of information caused by increased payments to private providers, which go beyond the SUS unified procedures table, by the State and municipalities. This makes it difficult to monitor both the expenditure and use, which is a limit of results analyzed in this and other studies ${ }^{24,28}$. On the other hand, it helps highlight the need for improvement of SUS current information systems, in order to capture the changes in the financing of medical care in the public sphere.

If the management of health technologies is taking steps to be deployed in the country, it may count as an advantage with the scope of official databases, to achieve a more efficient use of available resources, guiding investment and promoting effectiveness and quality of health care. It would also allow to formulate hypotheses to be further addressed in more detailed studies, using qualitative methodologies, to understand the behavior of the agents involved in various industries. It is therefore important to investigate the work relations and remuneration models of providers, regulation of demand, the competitive strategies of economic agents involved, the standards of medical practice, among several factors that may explain the patterns found for supply and use, whose clarification may provide society with information and clarity about the decisions to be made. In the case of Rio de Janeiro, taking into account the necessity of greater explanatory and critical depth, it is important to note that this article is part of a larger research project aimed at understanding the structure and dynamics of the market of in hemodynamics services in State of Rio de Janeiro, as a significant economic sector in shaping the quality and costs of care for cardiovascular problems, within a broader context of strengthening the State's Centers for Technology Assessment in Health.

\title{
R E S U M O
}

\begin{abstract}
Objetivo. analisar a oferta dos equipamentos e a utilização dos procedimentos inerentes aos serviços públicos de hemodinâmica no estado do Rio de Janeiro, Brasil. Métodos. Estudo exploratório, a partir de bancos de dados oficiais: pesquisa AMS do IBGE, CNES, AlH e APAC, e da ANS. O período de análise da oferta foi de 1999 a 2009 e o da utilização, de 2008 a outubro de 2012. Resultados. Desde 1999 há crescimento na aquisição dos equipamentos de hemodinâmica. O setor privado concentra grande parte da oferta, mas vem reduzindo sua disponibilidade ao Sistema Único de Saúde (SUS). A taxa de equipamentos pela população supera a de alguns países ricos. Quanto à oferta, havia, no Rio de Janeiro, em 2009, uma taxa de 4,1 aparelhos por milhão de habitantes maior do que no Brasil, de 3,4, mas considerando apenas a oferta para o SUS, os valores são semelhantes, de 1,6 e 1,5. Conclusão. Os procedimentos de cardiologia intervencionista cresceram entre 2008 e 2011 no RJ mas os hospitais públicos na sua maioria têm reduzido a produção e os privados aumentado, resultando no encaminhamento dos usuários do SUS para realizar os procedimentos a grandes distâncias.
\end{abstract}

Palavras-chave: Angioplastia. Cateterismo cardíaco. Hemodinâmica. Serviços de Saúde/utilização. Economia da saúde.

\section{REFERENCES}

1. Canevaro L. Aspectos físicos e técnicos da radiologia intervencionista. Rev Bras Fís Med. 2009;3(1):101-15.

2. Hillman BJ. Government health policy and the diffusion of new medical devices. Health Serv Res. 1986;21(5):681-711.

3. Geyman JP. The corporate transformation of medicine and its impacts on costs and access to care. J Am Board Fam Pract. 2003; 16(5):443-54

4. Calil SJ. Análise do setor de saúde no Brasil na área de equipamentos médico-hospitalares. In: Negri B, Di Giovanni G, organizadores. Brasil: radiografia da saúde. Campinas: Unicamp; 2001. p.91-121.

5. Brasil. Ministério da Saúde. Secretaria de Ciência, Tecnologia e Insumos Estratégicos. Departamento de Ciência e Tecnologia. Política Nacional de Gestão de Tecnologias em Saúde. Brasília, DF: Ministério da Saúde, 2011. 48 p. (Série B. Textos Básicos em Saúde). Disponível em: 200.214.130.94/rebrats/publicações/PNGTS.pdf.

6. Silva HP, Viana AL. Health technology diffusion in developing countries: a case study of CT scanners in Brazil. Health Policy Plan. 2011;26(5):385-94
7. Mendonça CS, Reis AT, Moraes JC, organizadores. A Política de Regulação no Brasil. Brasília: Organização Pan-Americana da Saúde, 2006. 116 p. (Série técnica desenvolvimento de sistemas e serviços de saúde.

8. US Congress, Office of Technology Assessment. Health Care Technology and its Assessment in Eight Countries. Washington, DC: US Government Printing Office; 1995. Report OTA-BP-H-140.

9. Oh EH, Imanaka Y, Evans E. Determinants of the diffusion of computed tomography and magnetic resonance imaging. Int J Technol Assess Health Care. 1985:21(1):73-80

10. Kazanjian A, Friesen K. Defusing technology. Technology diffusion in British Columbia. Int J Technol Assess Health Care. 1993;9(1):4661.

11. Rodrigues RM. Análise do mercado privado de diagnóstico por imagem do município de Macaé e suas interrelações com o processo regulatório local [dissertação]. Rio de Janeiro: Universidade Federal do Rio de Janeiro, Instituto de Estudos de Saúde Coletiva; 2008.

12. Viana AL, Silva HP. Avaliando a difusão de tecnologias médicas no sistema de saúde privado no Brasil: o caso da tomografia por 
emissão de pósitrons (PET). Rev Bras Saude Mater Infant. 2010;10 (Supl. 1):s187-200

13. Caetano R, Vianna CMM. Processo de Inovação tecnológica em saúde: uma análise a partir da organização industrial. Cad saúde colet. 2006;14(1):95-112

14. Brasil. Ministério da Saúde. Secretaria-Executiva. Área de Economia da Saúde e Desenvolvimento. Avaliação de tecnologias em saúde: ferramentas para a gestão do SUS. Brasília, DF: Ministério da Saúde, 2009. 110 p. (Série A. Normas e Manuais Técnicos. Disponível em: bvsms.saude.gov.br/bvs/publicações/ avaliação_tecnologias_saude_ferramentas_gestao.pdf.

15. James $A E$, Perry $S$, Warner SE, Chapman JE, Zaner RM. The diffusion of medical technology: free enterprise and regulatory models in the USA. J Med Ethics. 1991;17(3):150-5.

16. Gottschall CAM. 1929-2009: 80 anos de cateterismo cardíaco uma história dentro da história. Rev Bras Cardiol Invasiva. 2009;17(2):246-68.

17. Gutierrez FLBR. Difusão da angioplastia coronariana [dissertação]. Rio de Janeiro: Universidade do Estado do Rio de Janeiro, Instituto de Medicina Social; 2010

18. A Tomografia Computadorizada de múltiplos detectores no diagnóstico da doença arterial coronariana. BRATS; 2008; 3(4):1-8.

19. Sociedade Brasileira de Hemodinâmica e Cardiologia Intervencionista. Manual de Orientação para Serviços de Hemodinâmica e Cardiologia Intervencionista. Disponível em: http:/ /sbhci.org.br/wp-content/uploads/2010/08/ SBHCI_projQualidae_Manual19jul2012.pdf.

20. Getzen T. Health economics and financing. 3rd ed. Hoboken, NJ: Wiley; 2006.

21. Travassos C, Martins M. Uma revisão sobre os conceitos de acesso e utilização de serviços de saúde. Cad Saúde Pública. 2004;20(Suppl 2):S190-8.

22. Ko DT, Tu JV, Samadashvili Z, Guo H, Alter DA, Cantor WJ, et al Temporal trends in the use of percutaneous coronary intervention and coronary artery bypass surgery in New York State and Ontario. Circulation. 2010;121(24):2635-44.
23. Favaretti C, Mariotto A. Time trends in the utilization of cardiac catheterization procedures in Italy, 1983-93. Int J Technol Assess Health Care. 1996;12(3):518-23.

24. Pinto AMS, Pinheiro RS. Utilização de cirurgias cardíacas de alta complexidade no Estado do Rio de Janeiro numa perspectiva regionalizada: SIH-SUS - 1999 a 2007. Cad saúde colet. 2010;18(3):445-55.

25. Cardoso CR, Prestes EP, Cardoso CO, Beulke R. Contribuição do planejamento orçamentário no gerenciamento do laboratório de hemodinâmica: simulação aplicada à gestão dos serviços de hemodinâmica. Rev Bras Cardiol Invasiva. 2010;18(1):62-7.

26. OECD. Cardiac produces (coronary angioplasty). In: Health at a glance: Europe 2012. OECD Publishing; 2012

27. Mangione JA. Intervenção coronária percutânea no Brasil. Quais são os nossos números? Rev Bras Cardiol Invasiva. 2006;14(3):26772.

28. Viacava F, Porto S, Laguardia J, Moreira RS, Ugá MAD. Diferenças regionais no acesso à cirurgia cardiovascular no Brasil, 2002-2010. Ciênc saúde coletiva. 2012;17(11):2963-9.

29. State of Tennessee. Certificate of need standards and criteria for cardiac catheterization services; 2009. Disponível em: http:// tennessee.gov/hsda/con_standard_docs/ Cardiac\%20Catheterization\%20Services.pdf.

30. West Virginia Health Care Authority. Cardiac Catheterization Standards; 2008. Disponível em: http://www.hcawv.org/ CertofNeed/Support/CardiacCath.pdf.

Received on $28 / 11 / 2013$

Accepted for publication 01/02/2014

Conflict of interest: none.

Source of funding: FAPERJ - APQ 1 - 111 - 411/2012.

\section{Mailing address:}

Maria de Fátima Siliansky of Andreazzi

E-mail:siliansky@iesc.ufr.br 